\title{
Development and application of RP-HPLC method for dissolution study of oral formulations containing amlodipine besylate
}

\author{
Harshal Ashok Pawar ${ }^{1 * *} \&$ Akanksha Yadav ${ }^{2}$ \\ ${ }^{1}$ Asst. Professor \& Head, Department of Quality Assurance, Dr. L. H. Hiranandani College of Pharmacy, Ulhasnagar, Maharashtra, India \\ ${ }^{2}$ Research scholar, Department of Quality Assurance, Dr. L. H. Hiranandani College of Pharmacy, Ulhasnagar, Maharashtra, India \\ E-mail: harshal.dlhhcop@gmail.com
}

Received 20 June 2014; accepted 25 July 2014

\begin{abstract}
A rapid, robust and specific reversed-phase HPLC method has been developed and validated for quantitative estimation of amlodipine besylate in the dissolution study of oral films by direct injections of aqueous solutions. The study involve isocratic elution of amlodipine besylate in Zorbax ${ }^{\circledR}$ Eclipse XDB-C18 analytical column using buffer (0.7\% aqueous triethylamine adjusted to $p \mathrm{H} 3.0$ with orthophosphoric acid) and methanol in the ratio of 40:60 (v/v). The aqueous solutions are analysed at a flow rate of $1.0 \mathrm{~mL} / \mathrm{min}$ at $239 \mathrm{~nm}$. The method presents linearity $\left(r^{2}=0.999\right)$ in the concentration range $20-150 \mu \mathrm{g} / \mathrm{mL}$. The result indicates good recoveries ranging from $98.06 \%$ to $99.22 \%$. The method show good precision with $\%$ RSD value less than 2. All the validation parameters are within the acceptance range. The developed method can be successfully employed for in-vitro dissolution and routine analysis of formulations containing Amlodipine besylate.
\end{abstract}

Keywords: Amlodipine besylate, Filter evaluation, HPLC, ICH guideline, Method validation, Pharmaceutical film.

Amlodipine besylate (AMB) \{3-Ethyl 5-methyl (4RS)-2-[(2-aminoethoxy)methyl]-4(2-chlorophenyl)6-methyl-1,4-dihydropyridine-3,5-dicarboxylate benzene sulfonate $\}$ is a dihydropyridine calcium channel blocker indicated for the treatment of hypertension and Coronary Artery Disease ${ }^{1,2}$. Its molecular formula is $\mathrm{C}_{20} \mathrm{H}_{25} \mathrm{ClN}_{2} \mathrm{O}_{5} \cdot \mathrm{C}_{6} \mathrm{H}_{6} \mathrm{O}_{3} \mathrm{~S}$, formula weight is $567.05^{1}$. Amlodipine is well absorbed following oral administration resulting in moderately high absolute bioavailability of $64 \%{ }^{3}$. Following administration of $2.5,5$, and $10 \mathrm{mg}$ single oral dose, mean $\mathrm{T}_{\text {max }}$ values ranging from $5.6 \mathrm{~h}$ to $6.4 \mathrm{~h}$ is reported and is $97 \%$ bound to plasma proteins ${ }^{4}$. It is extensively but slowly metabolised $^{2}$. AMB is available in tablet and capsule dosage forms and is recommended as monotherapy or as a component of combination therapy for the treatment of angina pectoris and hypertension ${ }^{5}$. Some of the brands include Norvasc ${ }^{\circledR}$, Caduet $^{\circledR}$, Lotrel ${ }^{\circledR}$, Azor $^{\circledR}$ and Tekamlo $^{\circledR 6}$. AMB is available in $2.5,5$ and $10 \mathrm{mg}$ oral dose alone and in combination with other drugs with $10 \mathrm{mg} /$ day being the maximum daily dose. AMB orally disintegrating tablet is official in the United States Pharmacopoeia ${ }^{7}$. Literature survey revealed voltametric determination of AMB in human urine and pharmaceuticals ${ }^{8}$. Also, LC-MS and planar chromatography method was reported in biologicals ${ }^{9}$. Planar chromatography methods are also reported for bulk drug and combination tablet dosage form ${ }^{10-12}$. GC method was also proposed following trimethylacetyl derivatization in human plasma as matrix using ECD $^{13}$. GC-MS, HPLC, spectroscopic methods are also reported for drug substance and AMB pharmaceutical formulation (tablets) ${ }^{14-19}$. Films for oral drug delivery most recently were made official in the European Pharmacopoeia, edition 7.4 and subordinated to the monograph 'oromucosal preparations ${ }^{20}$. Since, the literature survey did not reveal determination of AMB in oral film formulation by HPLC, the present research work was undertaken.

\section{Experimental Section}

\section{Materials}

Amlodipine besylate (99.85\% purity) was obtained from Flamingo Pharmaceuticals Ltd., Mumbai, India. HPLC grade methanol and orthophosphoric acid were procured from Rankem, Mumbai, India. Triethylamine was obtained from SD Fine chemicals, Mumbai, India. All the chemicals and reagents used were of AR grade.

\section{Instrumentation and Chromatographic conditions}

HPLC system (Agilent Technologies 1200 series) equipped with quaternary pump, manual sampler, column heater and UV-visible Variable Wavelength 
Detector (1200 VWD) was employed for analysis. Analysis of aqueous solutions was carried out at $239 \mathrm{~nm}$ with Zorbax $^{\circledR}$ Eclipse XDB-C18 reversed-phase analytical column $(4.6 \times 150 \mathrm{~mm}, 5 \mu \mathrm{m})$. The isocratic mobile phase consisted of a mixture of buffer $(0.7 \%$ aqueous triethylamine adjusted to $p \mathrm{H} 3.0$ with orthophosphoric acid) and methanol in the ratio of 40:60 (v/v) throughout the analysis. The mobile phase was degassed by vacuum filtration before use. The flow rate of the mobile phase was $1.0 \mathrm{~mL} / \mathrm{min}$ and total run time was $8 \mathrm{~min}$. The column temperature was controlled at $30^{\circ} \mathrm{C}$ and injection volume was $20 \mu \mathrm{L}$. Chromatographic data was acquired using ChemStation software (Agilent Technologies).

\section{Preparation of AMB standard solution}

AMB stock solution was prepared by dissolving $10.0 \mathrm{mg}$ of AMB in $0.01 \mathrm{M} \mathrm{HCl}$ by sonication into $100 \mathrm{~mL}$ volumetric flask and the final volume was made using $0.01 \mathrm{M} \mathrm{HCl}$ to get the final concentration of $100 \mu \mathrm{g} / \mathrm{mL}$. Further dilutions were made to obtain standard solution of $5 \mu \mathrm{g} / \mathrm{mL}$.

\section{Formulation development}

Oral films of AMB $2.5 \mathrm{mg}$ were prepared by solvent casting method using synthetic and natural polymers. The prepared polymer solution was casted on polypropylene petri dish, dried and the film formed was utilized for further evaluation and HPLC analysis ${ }^{21,22}$. The oral films were evaluated for drug content and the results obtained were within accepted limit.

\section{Dissolution testing}

USP XXIII paddle (USP type II) dissolution apparatus was used with $500 \mathrm{ml}$ of $0.01 \mathrm{M} \mathrm{HCl}$ as dissolution medium that was freshly prepared each day of use and maintained at $37 \pm 0.5^{\circ} \mathrm{C}$ with $50 \mathrm{rpm}$ for analysis ${ }^{23}$. Each dissolution study was performed on six film samples. The aliquots of samples $(1 \mathrm{~mL})$ were withdrawn at the end of dissolution (at 270 s). These samples were centrifuged for $20 \mathrm{~min}$ and the supernatent solution was analyzed by HPLC.

\section{Method Validation}

The method was validated for parameters like precision, linearity, accuracy, specificity, robustness as per the ICH guideline ${ }^{24}$.

\section{Results and Discussion}

$\lambda_{\max }$ for AMB was determined by UV-VIS spectroscopy by preparing standard solution in the dissolution media $(0.01 \mathrm{M} \mathrm{HCl})$. The peak of maximum absorbance wavelength (max) was observed. The result indicated $\lambda_{\max }$ at $239 \mathrm{~nm}$ with $0.3021 \mathrm{AU}$ for 10 $\mu \mathrm{g} / \mathrm{mL}$ which was further used for HPLC method development.

\section{HPLC method development}

Amlodipine besylate is less polar molecule hence strongly retained on reversed-phase HPLC columns and is freely soluble in organic solvents like methanol, ethanol, DMSO. The column selection has been done on the basis of backpressure, peak shape, theoretical plates and day-to-day reproducibility of the retention time on Hypersil ${ }^{\circledR}$ BDS C18 column and Zorbax ${ }^{\circledR}$ Eclipse XDB-C18 column.

During method development, use of acetonitrile and methanol resulted in asymmetric peaks and peak tailing $>2$. To reduce the run time and improve the peak symmetry, the concentration of the organic portion of the mobile phase was varied, still USP peak tailing was observed $>2$. Hence, triethylamine $(0.7 \%$ aqueous solution) was added to minimize peak tailing. At the reported concentration of buffer $(0.7 \%$ aqueous triethylamine adjusted to $p \mathrm{H} 3.0$ with orthophosphoric acid) and methanol in the ratio of 40:60 (v/v) the USP tailing factor was within the acceptable limit resulting in good peak symmetry. A flow rate of $0.4 \mathrm{~mL} / \mathrm{min}$ resulted in drug retention time beyond $10 \mathrm{~min}$ that was more time consuming. Hence, the mobile phase was optimized at $1.0 \mathrm{~mL} / \mathrm{min}$ that resulted in lower retention time around $4.8 \mathrm{~min}$. Also, the less run time comparatively consumes less mobile phase solvents proving to be cost-effective during routine analysis. In this study a simple, rapid and robust method for analysis of amlodipine besylate in dissolution samples by direct injections of aqueous solutions was developed and validated. The present proposed method was compared with the reported methods in the literature shown in Table 1.

\section{System suitability and System precision}

The system suitability tests are parameters that confirm the validity of a well behaved chromatographic system. Instrument performance parameters such as peak area \%RSD and USP tailing factor were established. Six replicate injections of the standard solutions were carried out for analyzing system precision. Percent relative standard deviation (\%RSD) was lower than $2 \%$. The $\%$ RSD for mean peak area was $0.78 \%$, mean USP tailing factor was 1.44 , theoretical plates $>2000$. The $\%$ RSD for six 
Table 1 - Comparison of the performance characteristics of the present research method with the published methods

\begin{tabular}{|c|c|c|c|c|c|}
\hline $\begin{array}{l}\text { Stationary } \\
\text { phase }\end{array}$ & Mobile phase & Detection & Linearity; LOD/LOQ & Application & Reference \\
\hline C18 & $\begin{array}{l}\text { Methanol- } 0.04 \mathrm{M} \text { ammonium } \\
\text { acetate-acetonitrile } \\
(38: 38: 24 \mathrm{v} / \mathrm{v} / \mathrm{v})+0.02 \% \\
\text { TEA (final } p \mathrm{H} 7.1)\end{array}$ & $\mathrm{UV}$ at $240 \mathrm{~nm}$ & $2.5-100 \mathrm{ng} / \mathrm{mL}$ & $\begin{array}{l}\text { Pharmacokinetic } \\
\text { studies in rats }\end{array}$ & 25 \\
\hline $\mathrm{C} 18$ & $\begin{array}{l}\text { Acetonitrile-methanol- } p \mathrm{H} 3.0 \text {, } \\
\text { triethylamine solution }(15: 35: 50 \\
\mathrm{v} / \mathrm{v} / \mathrm{v})\end{array}$ & $\mathrm{UV}$ at $237 \mathrm{~nm}$ & $\begin{array}{l}0.39-1.56 \mu \mathrm{g} / \mathrm{mL} \\
\text { LOD: } 0.02 \mu \mathrm{g} / \mathrm{mL} \\
\text { LOQ: } 0.08 \mu \mathrm{g} / \mathrm{mL}\end{array}$ & $\begin{array}{l}\text { Detection of } \\
\text { amlodipine besylate } \\
\text { residues in swab } \\
\text { samples }\end{array}$ & 26 \\
\hline $\mathrm{C} 18$ & $\begin{array}{l}\text { (A) } 0.04 \mathrm{M} \text { Ammonium acetate- } \\
\text { methanol-acetonitrile } \\
(30: 30: 40 \mathrm{v} / \mathrm{v} / \mathrm{v}) ;(\mathrm{B}) 1 \% \text { acetic } \\
\text { acid-methanol }(1: 1 \mathrm{v} / \mathrm{v})\end{array}$ & $\begin{array}{l}\text { (A) UV at } 240 \mathrm{~nm} \text {; } \\
\text { (B) MS at } 2 \mathrm{kV} \text { soft } \\
\text { ionization with } \\
\text { positive mode }\end{array}$ & - & - & 27 \\
\hline C18 & $\begin{array}{l}1 \% \text { Triethylamine }(p \mathrm{H} 3.0)- \\
\text { acetonitrile }(65: 35 \mathrm{v} / \mathrm{v})\end{array}$ & $\mathrm{UV}$ at $220 \mathrm{~nm}$ & $\begin{array}{l}75-180 \mathrm{ppm} \\
\text { LOQ:21-35 ppm }\end{array}$ & $\begin{array}{l}\text { Quantification of alkyl } \\
\text { benzene sulfonates in } \\
\text { amlodipine besylate }\end{array}$ & 28 \\
\hline $\mathrm{C} 18$ & $\begin{array}{l}\text { Acetonitrile and } 0.05 \mathrm{M} \text { sodium } \\
\text { dihydrogen phosphate buffer } \\
(60: 40) \mathrm{pH} 6\end{array}$ & $\mathrm{UV}$ at $254 \mathrm{~nm}$ & $\begin{array}{l}\text { amlodipine besylate: } \\
5-30 \mu \mathrm{g} / \mathrm{mL} \text { and } \\
\text { telmisartan: } 10-60 \mu \mathrm{g} / \mathrm{mL}\end{array}$ & $\begin{array}{l}\text { Pharmaceutical dosage } \\
\text { form }\end{array}$ & 29 \\
\hline $\mathrm{C} 18$ & $\begin{array}{l}0.02 \mathrm{M} \text { Potassium dihydrogen } \\
\text { orthophosphate: acetonitrile } \\
(30: 70 \mathrm{v} / \mathrm{v}) \mathrm{pH} 5\end{array}$ & $\mathrm{UV}$ at $245 \mathrm{~nm}$ & $\begin{array}{l}\text { Telmisartan: } \\
\text { 32-96 } \mu \mathrm{g} / \mathrm{mL} \\
\text { Amlodipin: } 4-12 \mu \mathrm{g} / \mathrm{mL}\end{array}$ & Tablet dosage form & 30 \\
\hline $\mathrm{C} 18$ & $\begin{array}{l}\text { Buffer }(0.7 \% \text { aqueous } \\
\text { triethylamine }) p \mathrm{H} 3 \text { and } \\
\text { methanol in the ratio of } 40: 60 \\
(\mathrm{v} / \mathrm{v})\end{array}$ & $\mathrm{UV}$ at $239 \mathrm{~nm}$ & $20-150 \mu \mathrm{g} / \mathrm{mL}$ & $\begin{array}{l}\text { Pharmaceutical dosage } \\
\text { form (Oral Film) }\end{array}$ & $\begin{array}{l}\text { Present } \\
\text { Research } \\
\text { work }\end{array}$ \\
\hline
\end{tabular}

replicate injections of standard was $0.54 \%$. All the parameters tested met the acceptance criteria on all days. The result indicated that the chromatographic system is adequate for the intended analysis.

\section{Specificity}

HPLC chromatograms of blank solution (Fig. 1a), placebo solution (Fig. 1b), standard solution (Fig. 1c) and sample solutions obtained from dissolution testing of AMB oral films (Fig. 1d) indicated no interferences from the excipients with the drug peak indicating specificity of the method.

\section{Linearity}

Linearity of the method was confirmed by calibration curves for the analytical range of 20 to $150 \%$ of the standard concentration (Fig. 2). A linear curve was obtained with correlation coefficient of 0.999 between analyte peak and drug concentrations. The result showed good correlation between the peak areas and concentration of the drug. The results of regression analysis of the linearity data are indicated in Table 2. These data indicate that the method is linear within the specification limits.

\section{Method precision and Ruggedness}

The precision of an analytical procedure expresses the closeness of the agreement (degree of scatter) between a series of measurements obtained from the multiple samples of the same homogeneous sample under the prescribed conditions. Ruggedness of the method was evaluated by injecting six dissolution sample solutions using different analysts on different days. The percentage RSD obtained under different conditions was below 2\%. Table 3 represents the results of intermediate and intraday precision. The relative standard deviation (RSD) of both the tests was well within the desirable limit of NMT $2.0 \%$ which clearly indicated that the developed method is rugged.

\section{Recovery}

The accuracy was expressed as the percentage of analyte recovered by the assay method at three concentration levels 50, 100 and 150\%. The mean percentage recoveries (Accuracy) obtained was found between 95 to $105 \%$. The results of recovery study are summarized in Table 4.

\section{Robustness}

The analytical method must be robust to be employed in a quality control lab. The performance of the chromatographic system and the peak response factors were not significantly influenced by the altered parameters. The changes in the wavelength, $\pm 2 \mathrm{~nm}$ 


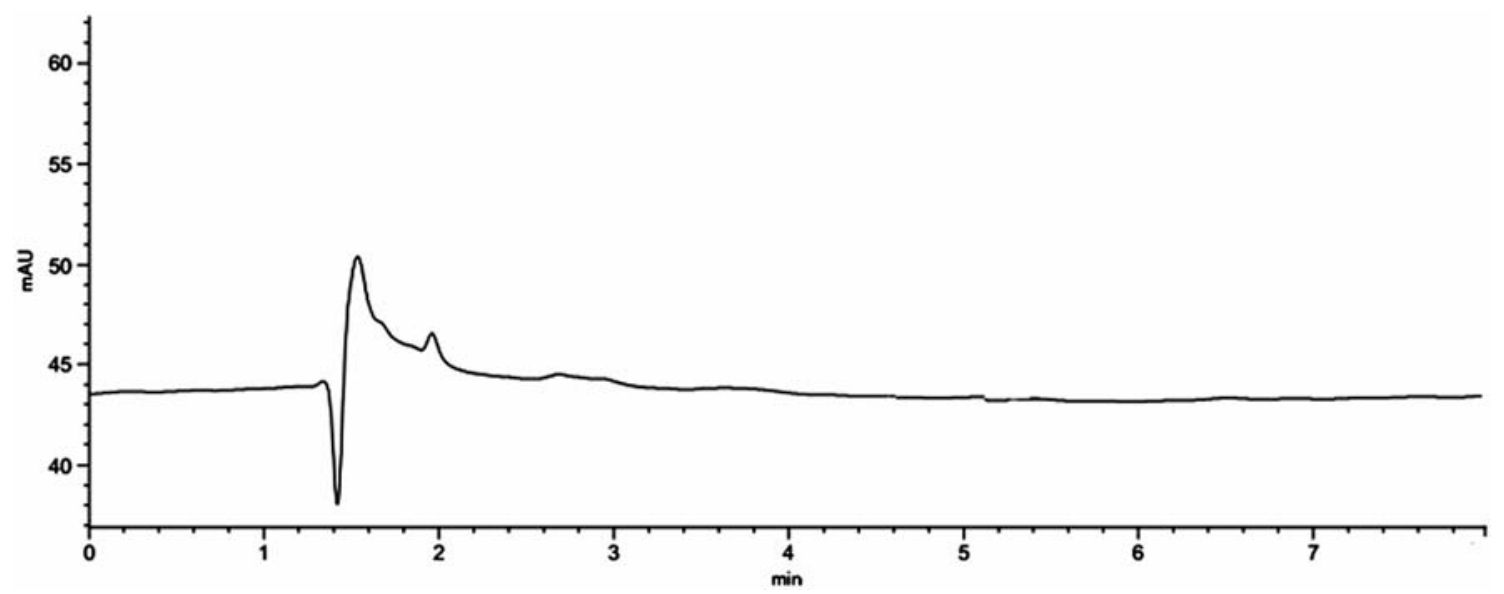

Fig. 1a - Chromatogram of blank solution

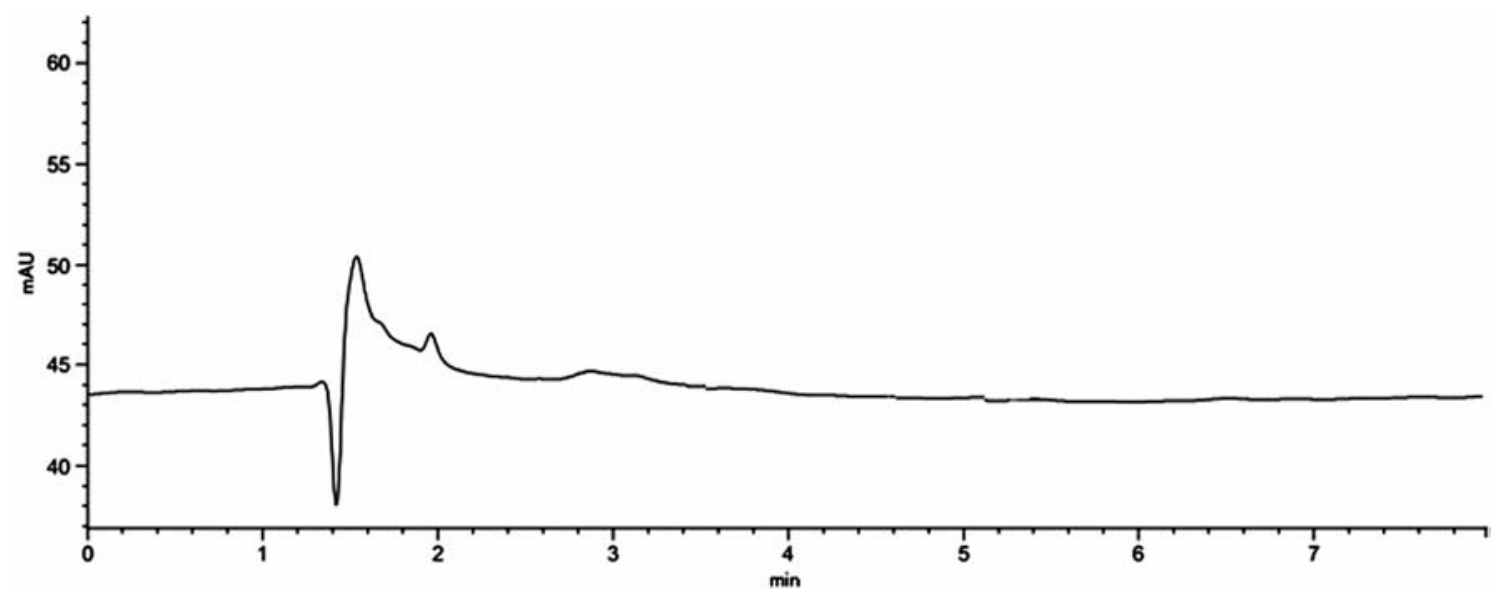

Fig. 1b - Chromatogram of placebo solution

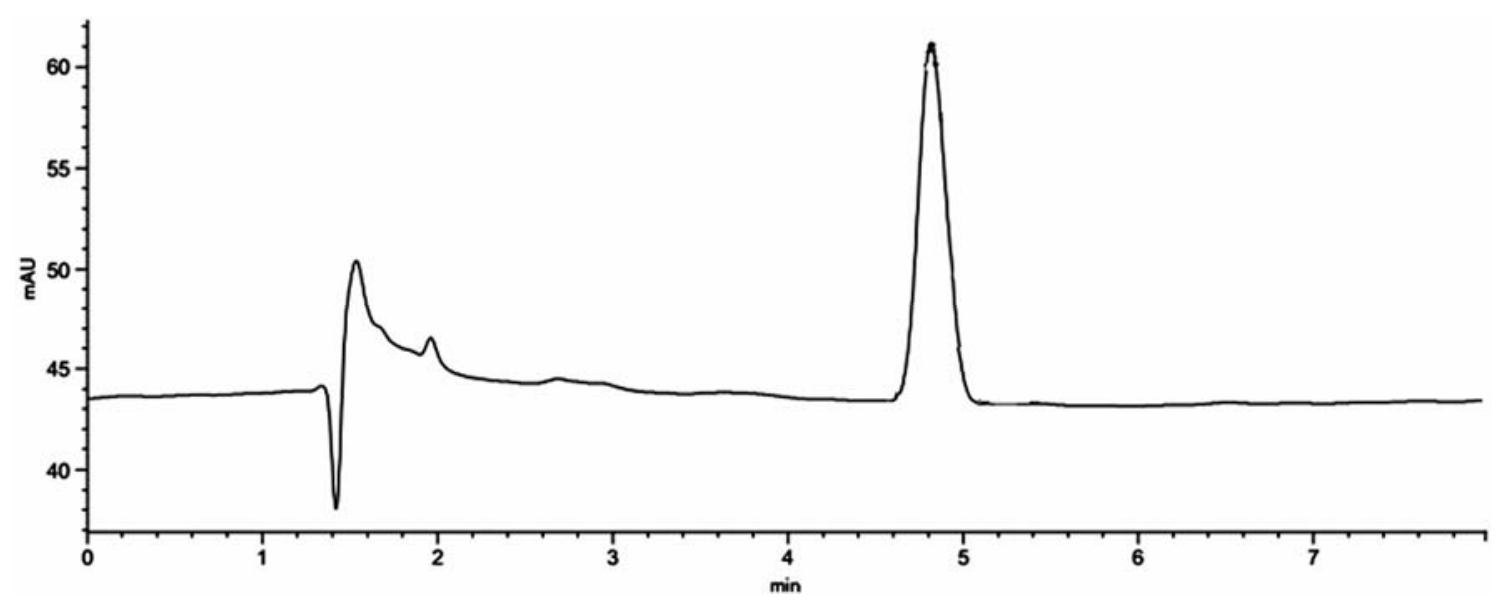

Fig. 1c - Chromatogram of standard AMB solution $(5 \mu \mathrm{g} / \mathrm{mL})$ 


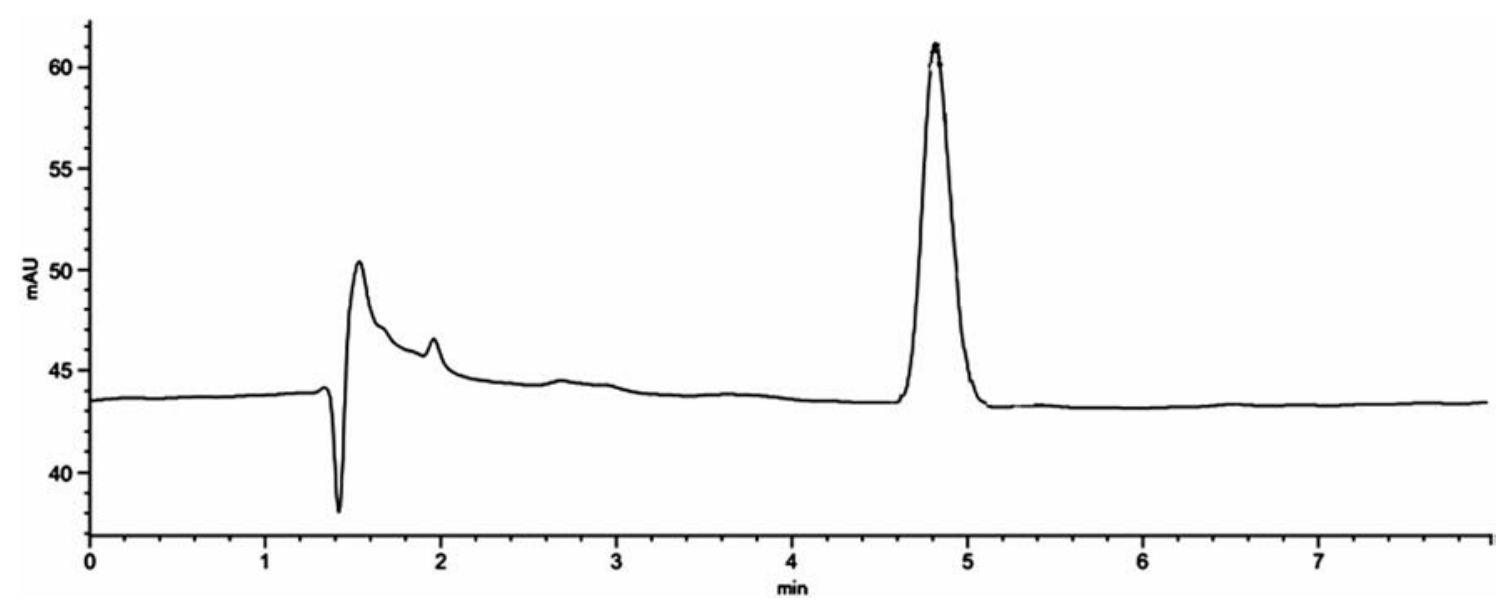

Fig. 1d - Chromatogram of dissolution sample solution of AMB

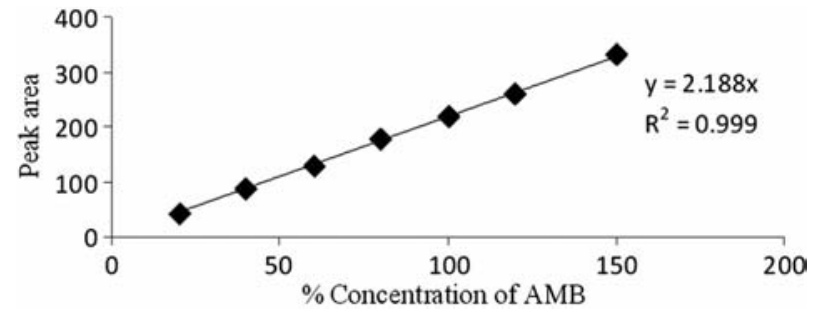

Fig. 2 - Calibration curve of $\%$ concentration of AMB w.r.t. calibration standard versus peak area

Table 2 - Results of regression analysis of the linearity data of AMB

$\begin{array}{lc}\text { Slope } & 2.21 \\ \text { Intercept } & -3.03 \\ \text { Correlation coefficient } & 0.999\end{array}$

$\mathrm{n}=3$

Table 3 - Results of Intermediate and Intraday Precision

\begin{tabular}{lcccc} 
& \multicolumn{4}{c}{ \% Dissolution } \\
\cline { 2 - 5 } Replicates & Day- 1 & Day- 2 & Column-I & Column-II \\
1 & 98.86 & 98.77 & 97.91 & 98.77 \\
2 & 98.77 & 98.56 & 98.55 & 98.38 \\
3 & 98.26 & 98.37 & 98.81 & 99.28 \\
4 & 98.40 & 97.40 & 99.29 & 98.77 \\
5 & 99.19 & 99.47 & 98.82 & 98.82 \\
6 & 97.86 & 99.29 & 99.18 & 99.17 \\
Mean & 98.56 & 98.64 & 98.76 & 98.82 \\
Standard deviation & 0.475 & 0.740 & 0.496 & 0.322 \\
\% RSD & 0.482 & 0.750 & 0.502 & 0.326 \\
Mean & 98.60 & & 98.81 & \\
Standard deviation & 0.595 & & 0.402 & \\
\% RSD & 0.603 & & 0.407 & \\
\hline
\end{tabular}

(237 nm, $241 \mathrm{~nm})$ and flow rate, $\pm 0.2 \mathrm{~mL} / \mathrm{min}$ $(0.8 \mathrm{~mL} / \mathrm{min}, 1.2 \mathrm{~mL} / \mathrm{min})$ did not show any significant variation in peak tailing, peak area or retention time. Hence the given method was found to be robust. The result of the robustness study is indicated in Table 5.

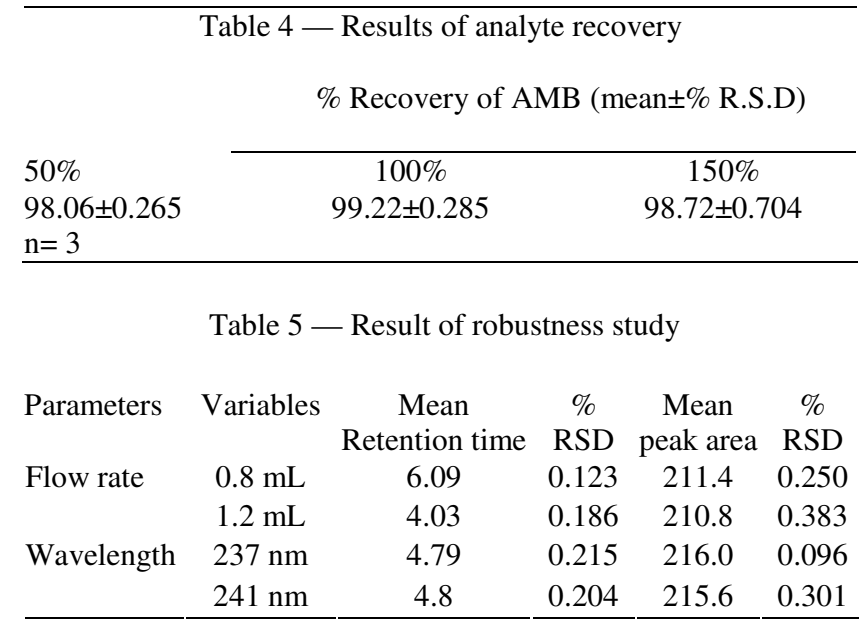

Table 6 - Short term solution stability for AMB

$\begin{array}{lccc} & 4 \mu \mathrm{g} / \mathrm{mL} & 5 \mu \mathrm{g} / \mathrm{mL} & 6 \mu \mathrm{g} / \mathrm{mL} \\ \text { Mean } & 3.96 & 5 & 5.94 \\ \text { S.D } & 0.014 & 0.028 & 0.0251 \\ \% \text { RSD } & 0.385 & 0.565 & 0.423 \\ \mathrm{n}=3 & & & \end{array}$

\section{Solution stability}

Stability studies indicated that the samples in concentration of 4,5 and $6 \mu \mathrm{g} / \mathrm{mL}$ were stable when stored for $24 \mathrm{~h}$ at room temperature. The results of the stability studies are given in Table 6 .

Filter evaluation A filter is acceptable for use if the results of the filtered portions approach 98$102 \%$ of the original concentrations of the unfiltered standard solution and the centrifuged sample solution. Standard and sample solutions were prepared in the dissolution medium, the solutions were either filtered through Whatman No. 41 filter paper or centrifuged. In both the tests, 
Table 7 — Filter evaluation data.

Centrifugation Filtration $(\mu \mathrm{g} / \mathrm{mL})$ $(\mu \mathrm{g} / \mathrm{mL})$

\begin{tabular}{lcc} 
Standard & & \\
Mean & 4.98 & 4.89 \\
S.D & 0.023 & 0.023 \\
\%RSD & 0.463 & 0.471 \\
Sample & & \\
Mean & 4.79 & 4.73 \\
S.D & 0.036 & 0.026 \\
\%RSD & 0.752 & 0.559 \\
n=3 & & \\
\hline
\end{tabular}

standard and sample solutions were analyzed for its peak response factors. The results did not show any significant variation (Table 7). The result demonstrates the absence of adsorption of AMB by the filter and therefore Whatman No. 41 filter paper is suitable in the dissolution test.

\section{Conclusion}

A simple, reproducible, isocratic HPLC method has been developed and validated for the quantitative determination of amlodipine besylate in the dissolution study of oral films using a UV detector. A complete dissolution of amlodipine besylate could be achieved after 270 seconds using USP apparatus II at $50 \mathrm{rpm}$ in $500 \mathrm{~mL}$ of dissolution medium $(0.01 \mathrm{M} \mathrm{HCl})$. The validation results indicated that the method is specific, accurate, linear, precise, rugged and robust. The run time is relatively short which enables rapid quantification of many samples in routine analysis. Thus the developed method can be successfully employed for in-vitro dissolution and routine analysis of formulations containing amlodipine besylate.

\section{Acknowledgement}

Authors are very much thankful to Dr. P.S. Gide, Principal of Hyderabad Sindh National Collegiate Boards (HSNCB's) Dr. L. H. Hiranandani College of Pharmacy, Ulhasnagar for his continuous support, guidance and encouragement.

\section{References}

1 The Merck Index, An Encyclopedia of Chemicals, Drugs, and Biologicals, 14th Edn, (Merck and Co., Inc, Whitehouse Station, NJ) 2006, 83.

2 Meredith P A \& Elliott H L, Clin Pharmacokin, 22 (1992) 22.

3 Faulkner J K, McGibney D, Chasseaud L F, Perry J L \& Taulor I W, Br J Clin Pharmacol, 22 (1986) 21.

4 Williams D M \& Cubeddu L X, J Clin Pharmacol, 28 (1988) 990.
5 Thacker H P, J Indian Med Assoc, 105 (2007) 180.

6 RxList, The internet Drug Index, http://www.rxlist.com/, (Accessed June 26 2012).

7 U S Food and Drug Administration Orange Book: Approved Drug Products with Therapeutic Equivalence Evaluations, http://www.accessdata.fda.gov/scripts/cder/ob/docs/tempai. cfm (Accessed June 26 2012).

8 Zhou Y, Li J, He X, Jia M, Liu M, Li H, Xiong Z, Fan Y \& Li W, J Pharm Biomed Anal, 83 (2013) 101.

9 Pandya K K, Satia M \& Gandhi T P, J Chromatogr B: Biomed Sci Appl, 667 (2) (1995) 315.

10 Argekar A P \& Powar S G, J Pharm Biomed Anal, 21 (2000) 1137.

11 Kamble A Y, Mahadik M V, Khatal L D \& Dhaneshwar S R, Anal Lett, 43 (2010) 251.

12 Ramadan N S, Mohamed H M \& Moustafa A A, Anal Lett, 43 (2010) 570.

13 Beresford A P, Macrae P V, Stopher D A \& Wood B A, J Chromatogr, 420 (1987) 178.

14 Mauer H H \& Arlt J W, J Anal Toxicol, 23 (1999) 73.

15 Carvalho M, Oliviera C H, Mendes G D, Sucupira M, Moraes M E \& Nucci G De, Biopharm Drug Dispos, 22 (2001) 383.

16 Kasawar G B \& Farooqui M N, Anal Sci, 25 (2009) 1495.

17 Yasuda T, Tanaka M \& Iba K, J Mass Spectrom, 31 (1996) 879.

18 Yeung P K F, Mosher S J \& Pollak P T, J Pharm Biomed Anal, 9 (1991) 565.

19 Sridhar K, Sastry C S P, Reddy M N, Sankar D G \& Srinivas K R, Anal Lett, 30 (1997) 121.

20 European Pharmacopoeia Commission. Oromucosal Preparations. In European Pharmacopoeia - edition 7.4; (European Directorate for the Quality of Medicines (EDQM): Strasbourg, France) 2012, 4257.

21 Dinge A \& Nagarsenkar M, AAPS Pharm Sci Tech, 9 (2) (2008) 349.

22 McConville J T \& Morales J O, European J Pharm Biopharm, 77 (2011) 187.

23 U S Food and Drug Administration. Dissolution methods. http://www.accessdata.fda.gov/scripts/cder/dissolution/ds p_SearchResults_Dissolutions.cfm?PrintAll=1 (Accessed July 24 2012)

24 International Conference of Harmonization- $\mathrm{ICH}$, "Validation of Analytical Procedures: Text and Methodology, Q2 (R1), 2005," Harmonised Tripartite Guideline, 2005

25 Yeung P K F, Mosher S J \& Pollak P T, J Pharm Biomed Anal, 9 (1991) 565.

26 Klinkenberg R, Streel B \& Ceccato A J, Pharm Biomed Anal, 2 (2003) 345.

27 Abdoh A, Al-Omari M M, Badwan A A \& Jaber A M Y, Pharm Develop Technol, 9 (2004) 15.

28 Raman N V V S S, Reddy K R, Prasad A V S S \& Ramakrishna K, J Pharm Biomed Anal, 48 (2008) 227.

29 Sinha S K, Shrivastava P K \& Shrivastava S K, Asian Pacific J Trop Biomed, (2012) S312.

30 Rajitha S, Biswal V B, Reddy D N \& Ramesh B, Int J Pharma Sci, 3 (2013) 365. 